\title{
Interactive Learning in the Preparation of Students 1-4 Grades
}

\author{
Hanna Byhar ${ }^{1, *}$, Iryna Pits ${ }^{1}$, Inna Prokop ${ }^{1}$, Krystyna Shevchuk $^{1}$, Olha Shestobuz $^{1} \&$ Olesia Makoviichuk $^{1}$ \\ ${ }^{1}$ Yuriy Fedkovych Chernivtsi National University, Chernivtsi, Ukraine \\ *Correspondence: Yuriy Fedkovych Chernivtsi National University, Chernivtsi, 58012, Ukraine. E-mail: \\ byharhann848@gmail.com
}

Received: December 7, 2021

Accepted: January 6, 2022 Online Published: January 17, 2022

doi:10.5430/jct.v11n1p87

URL: https://doi.org/10.5430/jct.v11n1p87

\begin{abstract}
The purpose of this study was to identify effective interactive methods in preparing students in grades 1-4, as well as to investigate their impact on learning outcomes. The work uses theoretical and empirical methods. The analysis of existing interactive teaching methods, their selection in accordance with the age characteristics of primary school students and educational needs. Also, a pedagogical experiment was carried out based on the implementation of the developed model of using interactive teaching methods in grades 1-4 of general secondary education institutions and monitoring the learning outcomes obtained in this case. A survey of teachers and students was carried out. The study showed that the use of interactive methods in the lessons of the Ukrainian language and mathematics contributes to the growth of students' interest in studying these disciplines. As a result, there is an increase in the level of educational achievements of students from average to sufficient, and in some cases from sufficient to high. Thus, in this work it is proved that the proposed model of teaching using interactive methods that take into account the age and individual characteristics of students is highly effective. Further research should be carried out with the aim of correcting existing interactive methods in accordance with the modern educational needs of students and their individual characteristics. Research is also needed to identify new interactive methods and study their impact on learning outcomes.
\end{abstract}

Keywords: speech skills, math skills, interactive model, academic achievements, educational needs

\section{Introduction}

Modern society lives in an era of rapid technological development. In turn, this leads to the fact that information quickly appears, generates its novelty and soon loses its relevance. Therefore, for each member of society, including children, it is important to learn how to navigate information, process and apply it. In such conditions, traditional methods, when the teacher is assigned the main role in the transfer of new material, are ineffective. In order for the educational process to be productive, it is necessary to present the educational material to students in an interesting way. One that motivates to learn, promotes rapid memorization, encourages the search for new ideas. This poses new challenges for the education system: to find and use teaching methods that can ensure the rapid and effective achievement of didactic goals and meet the educational needs of students. In short periods of time, it is important to allow children to receive the maximum possible amount of knowledge, to form the necessary skills and abilities. Interactive teaching methods meet these requirements. They are based on the involvement of students in the process of obtaining new educational information through active interaction with each other and with the teacher. The variety of such methods allows you to take into account the age and individual characteristics of each student, to motivate them. The teacher's ability to use them increases the cognitive activity of students and the level of their achievements. Despite the fact that in the scientific literature there are a number of works devoted to the study of the advantages and disadvantages of interactive teaching methods, the issue of their use in the process of preparing primary school students remains insufficiently studied.

The purpose of this study was to identify and research such interactive teaching methods that can be effectively used in the preparation of students in grades 1-4.

To achieve the set goals, it was necessary to solve the following tasks:

1) Investigate whether primary school teachers use interactive teaching methods in their professional activities; 
2) Design and implement a training model for students in grades 1-4, which is based on the use of interactive teaching methods;

3) Investigate the effectiveness of using the developed learning model in the assimilation of knowledge by students and the formation of skills.

\section{Literature Review}

The main task of the school is to transfer maximum knowledge of skills and abilities to students in an easy way for them (Shraddha et al., 2020). At the same time, it is necessary to take into account the educational needs, opportunities and age characteristics (Luyten et al., 2020) of each student in the class (Ismajli \& Imami-Morina, 2018). Studies (Puspitarini \& Hanif, 2019) have revealed low effectiveness of traditional teaching methods. At the same time, the teacher must be aware of the latest technologies, can use all available educational tools (Elliot \& Lashley, 2017; Mekacher, 2019), and also guide students to active practical activities in order to increase learning productivity (Alsawalha, 2018). The educational process should become interactive, attractive for students (Samat, 2020), and correspond to their age characteristics (Ponomarova \& Lebedenko, 2021). The teacher should also be proficient in quick methods of determining student satisfaction with the learning process, for example, by facial expressions (Guran et al., 2020; Lebedev et al., 2020).

In some states, this method of presenting new material is practiced, such as through the media (Iasha et al., 2018) or teaching on the radio (also called interactive radio training) (Elliot \& Lashley, 2017). The latter technique is relatively effective and relatively cheap. Although under these conditions, the interaction is one-way: students study the material presented on the radio, but there is no feedback. At the same time, a number of additional didactic materials have been developed, for example, printed ones. Through them, the teacher in the classroom can determine the degree of assimilation of the material by the students. This way of teaching helps to reduce the differences caused by the unequal training of teachers in these schools and other differences in educational areas of different educational institutions (Elliot \& Lashley, 2017).

Recently, emphasis has been placed on changing the functional roles of teacher and student. It has been proven (Elliot \& Lashley, 2017) that learning outcomes will be higher when the teacher does not act as a translator of new information to students. At the same time, students will not be passive recipients of it. It is much more important to organize the educational process so that students are active seekers of new knowledge. The teacher, in turn, should play the role of a coach, employee, team coordinator, advisor, monitoring and evaluation expert, and sometimes the student himself.

Interactive teaching methods, including: small group work, case studies), role-playing games, project method, collaborative learning (Veldman et al., 2020), can contribute to the effective achievement of the goals of modern educational programs (Bagila et al., 2019). They allow them to develop such skills in primary school students: creatively use the knowledge gained, speech skills, writing skills and reading comprehension, work in a group and independently, think critically (Bagila et al., 2019). At the same time, the latter skill can be developed if the student is given the opportunity to solve the posed educational problem on his own, relying on his own strength, knowledge, and experience (Oltievna \& Aktamovna, 2020). Also, interactive methods are effectively used in inclusive education (Parmigiani et al., 2020; Pitchford et al., 2018). They are effective in preparing future primary school teachers (Rotova, 2018).

The scientific literature provides examples of the implementation of an interactive learning model in educational practice. For example, (Kocman et al., 2020) describes the experience and results of the implementation of the method of joint design of scientific research of natural phenomena in the second grade. The relationship between learning style and interactive methods and student achievement is noted (Tomuletiu et al., 2011).

Learner-centered learning should take into account his interests. The modern student lives in a digital world and is constantly engaged in the processing of digital information. This, in turn, leads him to a desire to learn from his own experience (Anastasiadis et al., 2018). In this case, traditional teaching methods need to be used in a balanced way alongside those that make the learning process more interesting, fun, more motivating and enjoyable. The authors (Anastasiadis et al., 2018) consider the benefits of using digital games in teaching as an equal educational tool and interactive educational event.

ICT can also be not only audio and video broadcasters of educational material, but also a tool for increasing the activity of students in the process of assimilating knowledge, contributing to the development of creative abilities (Azam et al., 2019) and critical thinking 
(Shkvyr et al., 2020). ICT also helps to develop intellectual communication skills of students, teach to analyze, compare, evaluate information. Through ICT-based teaching methods, learners learn to make decisions and justify them. With the help of ICT, e-learning (Kacetl \& Semradova, 2020) and distance learning is possible. The latter form of education became compulsory during the pandemic (Fauzi \& Khusuma, 2020; Putri et al., 2020). Computer-based interactive multimedia applications are effective in primary education (Dita et al., 2021; Rachmadtullah et al., 2018), as well as programs aimed at preschool and primary school children (Outhwaite et al., 2019). The use of exercise videos increases the physical activity of students, which leads to increased physical self-efficacy and academic knowledge (Emeljanovas et al., 2018).

The use of an interactive teaching model in primary school helps to increase reading comprehension and memory development in students (Samat, 2020). The use of mobile applications contributes to the development of writing skills (Ien et al., 2017). Interactive programs that can be installed on a tablet or phone have a positive effect on the development of the mathematical abilities of students in grades 1-4 (Pitchford et al., 2018).

Interactive teaching methods in primary school can ensure active interaction of the student with the teacher and the learning environment, as well as make the student an active actor in the educational process (Shkvyr et al., 2020). These techniques can encourage student interaction, such as coaching one student with another in mathematics (Thurston et al., 2020). It is effective for students to reproduce the information received in other forms (Samat, 2020).

\section{Methods}

The research was carried out in five stages.

At the first stage, using a closed questionnaire, a survey was conducted of teachers of grades 1-4 of general secondary education institutions. It aimed to establish the degree of familiarization of teachers with interactive teaching methods, to investigate their attitude to these methods and the frequency of their use in the educational process in primary school.

At the second stage, a learning model was developed, involving the use of interactive methods in grades 1-4. At the same time, the age characteristics of students were taken into account and the requirements for the stages of education of students in primary school were met.

At the third stage of the study, which lasted for one academic year, the learning model obtained at the second stage was introduced into the educational process. The following interactive methods were used: "Microphone", "Brainstorming", "Take a position", "Studying-learning", "Working in pairs", "Talk-show", " Jigsaw", "Circle of ideas", " Aquarium ", " Role-playing games ". They were introduced in grades 1-4 of 18 institutions of general secondary education. Interactive methods were used in teaching such disciplines: Ukrainian language, Mathematics. The methods met the educational goals of the lesson, were selected taking into account the individual characteristics of each student in the class. The main purpose of using interactive teaching methods was to form students' language, spelling and punctuation skills and abilities, listening, reading, speaking. Also knowledge, skills and abilities in mathematics: computational skills; problem solving skills; execution of measurements and geometric constructions.

At the fourth stage, the results achieved were assessed. The evaluation criteria that were used in the study are shown in Table 1 (Indicative requirements for monitoring and evaluating the academic achievements of primary school students, 2016). Using a closed questionnaire, it was determined how students' attitudes towards learning changed during the experiment. 
Table 1. Objects and Indicators for Assessing the Educational Achievements of Primary School Students (Indicative requirements for monitoring and evaluating the academic achievements of primary school students, 2016)

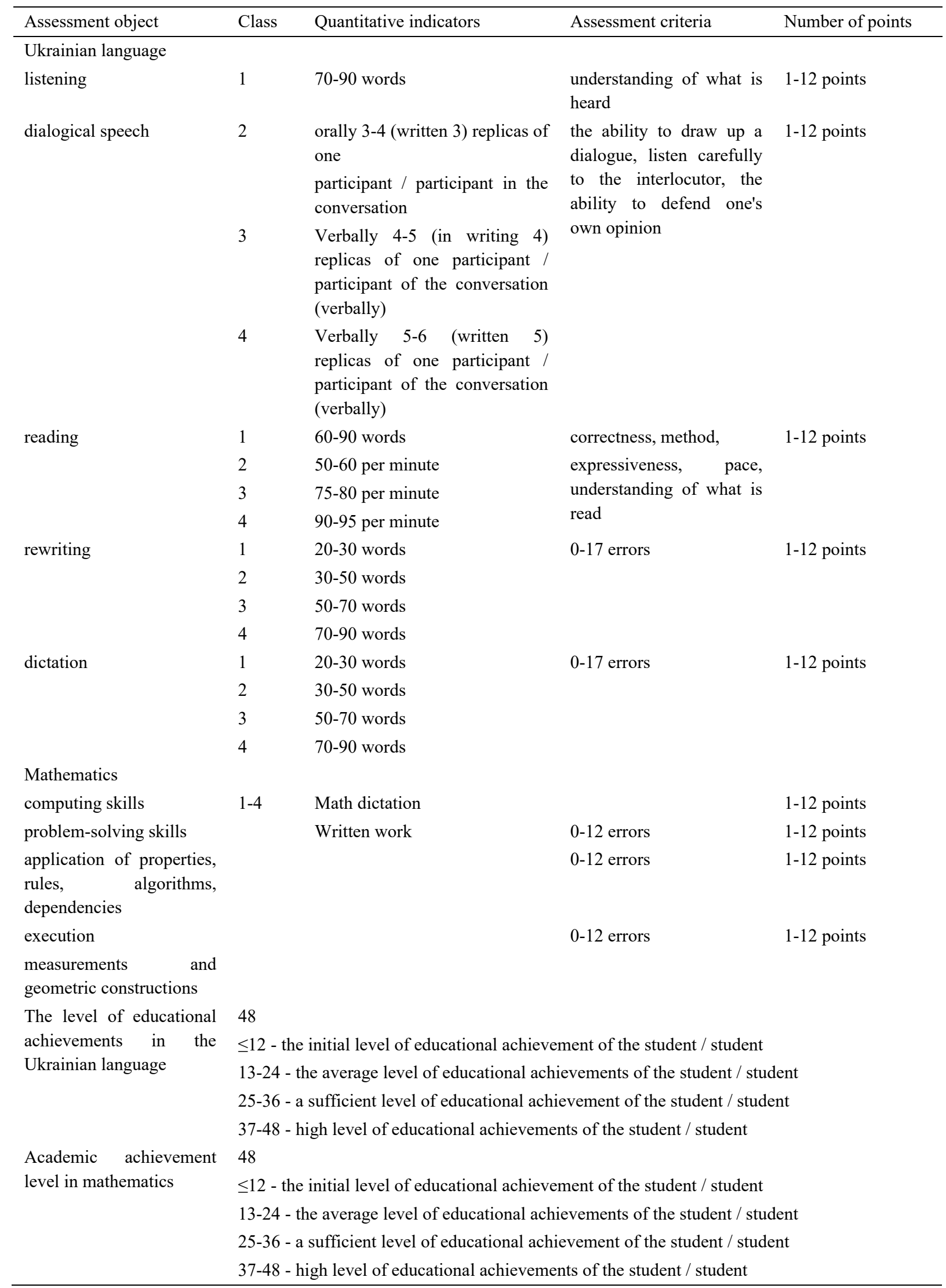


The sample consisted of 83 teachers who took part in the survey, 36 of them acted as experts: 18 were introduced to the methods of using interactive methods during teaching students in grades 1-4 and the criteria for assessing the effectiveness of the impact of these methods on the results achieved by students. They, after passing special instructions, practiced interactive teaching methods in experimental groups. The remaining 18 teachers were adherents of traditional teaching methods and used them in the educational process in the control groups. The sample also included 358 students enrolled in grades 1-4 in 18 institutions of general secondary education. Of these, 173 students were included in the experimental group, and 175 in the control group. In the experimental group, interactive teaching methods were introduced, in the control group - traditional methods, where the teacher is a translator of information and an active actor in the assimilation of knowledge by students and the formation of their skills and abilities.

The study used theoretical and empirical methods. In particular, the analysis of foreign experience in the use of interactive teaching methods and the experience of Ukrainian scientists regarding the use of interactive teaching methods in primary grades. We also used a pedagogical experiment, observations, and questionnaires. Two closed questionnaires were used. One was applied to the beginning of the experiment among teachers and was supposed to determine the attitude of teachers to interactive methods, their degree of proficiency in these methods and the frequency of use in the classroom. Another questionnaire was used before and after the experiment to determine how students' attitudes towards learning changed under the influence of interactive teaching methods. Participation in the survey was voluntary. The questionnaires were ethical. The results of the study were processed by mathematical methods of data processing using the Statistica software. Cohen's coefficient and Pearson's test were applied.

\section{Results}

The study involved primary school teachers belonging to different age groups. Also students in grades 1-4. The characteristics of the sample by age are presented in Table 2 .

Table 2. Age Characteristics of the Sample

\begin{tabular}{lllll}
\hline Teachers & & & & \\
\hline Age of teachers & $25-34$ & $35-44$ & $45-54$ & $55-65$ \\
Number of teachers & 17 & 32 & 21 & 13 \\
\hline Students & & & & \\
\hline Class & 1 & 2 & 3 & 5 \\
The number of students in the experimental / control group & $21 / 21$ & $48 / 49$ & $57 / 58$ & $52 / 52$ \\
\hline
\end{tabular}

A survey among primary school teachers of 18 institutions of general secondary education from five regions of Ukraine showed that the attitude of teachers to interactive teaching methods is different.

It depends on age, work experience, and personal attitude towards different teaching methods. The results of the survey of teachers are presented in Table 3 .

Among 83 surveyed primary school teachers, about $4 \%$ are not familiar with interactive teaching methods. At the same time, $76 \%$ of teachers believe that it is advisable to use interactive teaching methods in grades 1-4 of general secondary education institutions. And $72 \%$ of the respondents are already using these teaching methods in their professional activities. At the same time, such interactive methods as "Work in pairs" (63\%), "Role-playing games" (61\%) and "Brainstorming" (57\%) are most popular. Less than half of the cases use the methods "Teaching-learning " (45\%), "Microphone" (43\%), "Take a position" (32\%), "Talk show" (21\%). The least common are "Circle of Ideas" (14\%), "Aquarium" (14\%) and "Jigsaw" (16\%) (Figure 1). 
Table 3. Results of the Teacher Survey

\begin{tabular}{|c|c|c|c|c|c|}
\hline Age & $25-34$ & $35-44$ & $45-54$ & $55-65$ & Total persons $/ \%$ \\
\hline Question & \multicolumn{5}{|c|}{ Number of «Yes» answers } \\
\hline $\begin{array}{l}\text { Are you familiar with the interactive learning } \\
\text { methodology? }\end{array}$ & 17 & 32 & 20 & 11 & $80 / 96 \%$ \\
\hline $\begin{array}{l}\text { Do you think the use of interactive teaching } \\
\text { methods in primary school is appropriate and } \\
\text { effective? }\end{array}$ & 14 & 28 & 14 & 7 & $63 / 76 \%$ \\
\hline $\begin{array}{l}\text { Do you use interactive teaching methods in the } \\
\text { classroom? }\end{array}$ & 11 & 28 & 14 & 7 & $60 / 72 \%$ \\
\hline $\begin{array}{l}\text { Which of the following interactive methods do you } \\
\text { use in your teaching practice? }\end{array}$ & & 10 & 6 & 2 & $36 / 120$ \\
\hline «Microphone» & & & & & \\
\hline «Brainstorm» & 9 & 23 & 10 & 6 & $48 / 57 \%$ \\
\hline «Take a position» & 5 & 17 & 3 & 2 & $27 / 32 \%$ \\
\hline «Learning-learning» & 7 & 21 & 7 & 2 & $37 / 45 \%$ \\
\hline «Working in pairs» & 10 & 25 & 11 & 6 & $52 / 63 \%$ \\
\hline «Role-playing games» & 10 & 24 & 12 & 5 & $51 / 61 \%$ \\
\hline «Talk show» & 3 & 13 & 1 & 0 & $17 / 21 \%$ \\
\hline «Jigsaw» & 0 & 11 & 2 & 0 & $13 / 16 \%$ \\
\hline «Circle of Ideas» & 3 & 6 & 2 & 1 & $12 / 14 \%$ \\
\hline «Aquarium» & 2 & 9 & 1 & 0 & $12 / 14 \%$ \\
\hline
\end{tabular}

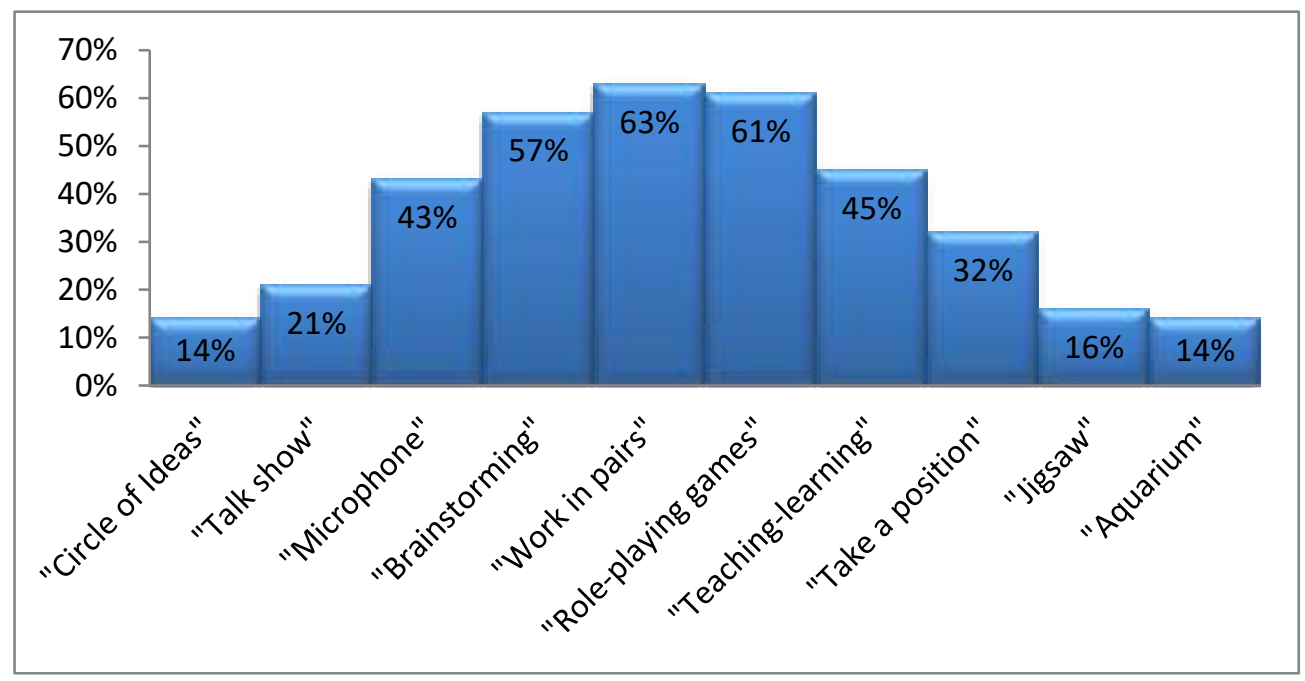

Figure 1. The Popularity of Interactive Methods Among the Interviewed Teachers

The model of using interactive teaching methods in grades 1-4 of general secondary education institutions in this work was designed in such a way that in grades 1 and 2, learning was carried out in accordance with the adaptation-game stage, in grades 3, 4 - in accordance with the main stage of learning. It was also taken into account that the chosen interactive teaching methods contribute to the active formation of students' knowledge, skills and abilities necessary for listening, dialogical speech, reading, cheating, writing dictations, in computing, in solving problems, applying properties, rules, algorithms, dependencies between quantities, measurements and geometric constructions (see Table 4). 
Table 4. Interactive Methods That Were Used to Develop the Corresponding speech and Mathematical Skills and Abilities

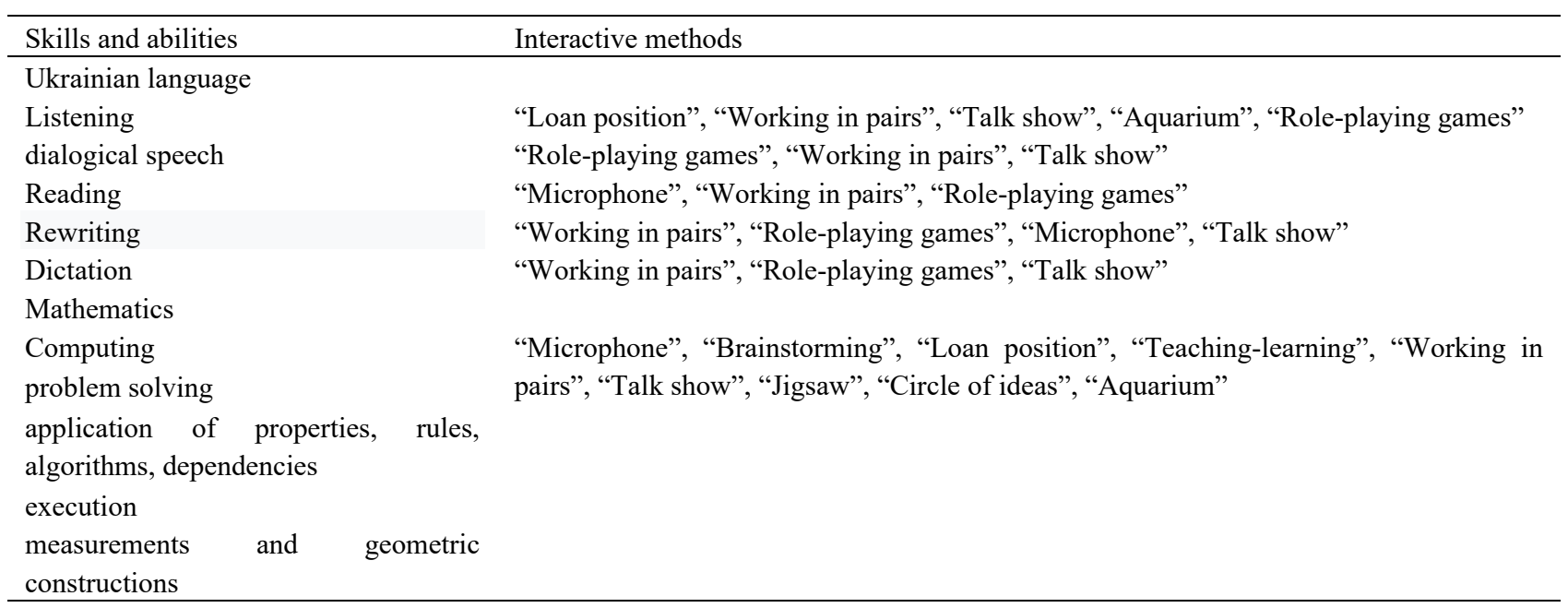

At the end of the academic year, after 9 months of applying the model of interactive teaching methods, an assessment and comparison of the level of educational achievements of students included in the experimental and control groups was carried out. Listening, dialogical speech, reading, copying and dictation of the Ukrainian language were assessed. Also, computational skills and abilities, skills and abilities of solving problems, applying properties, rules, algorithms, dependencies, performing measurements and geometric constructions in mathematics were assessed (Table 5). It was revealed that the use of a learning model that provides for the use of interactive methods leads to an increase in the level of student achievement (Figure 2-5).

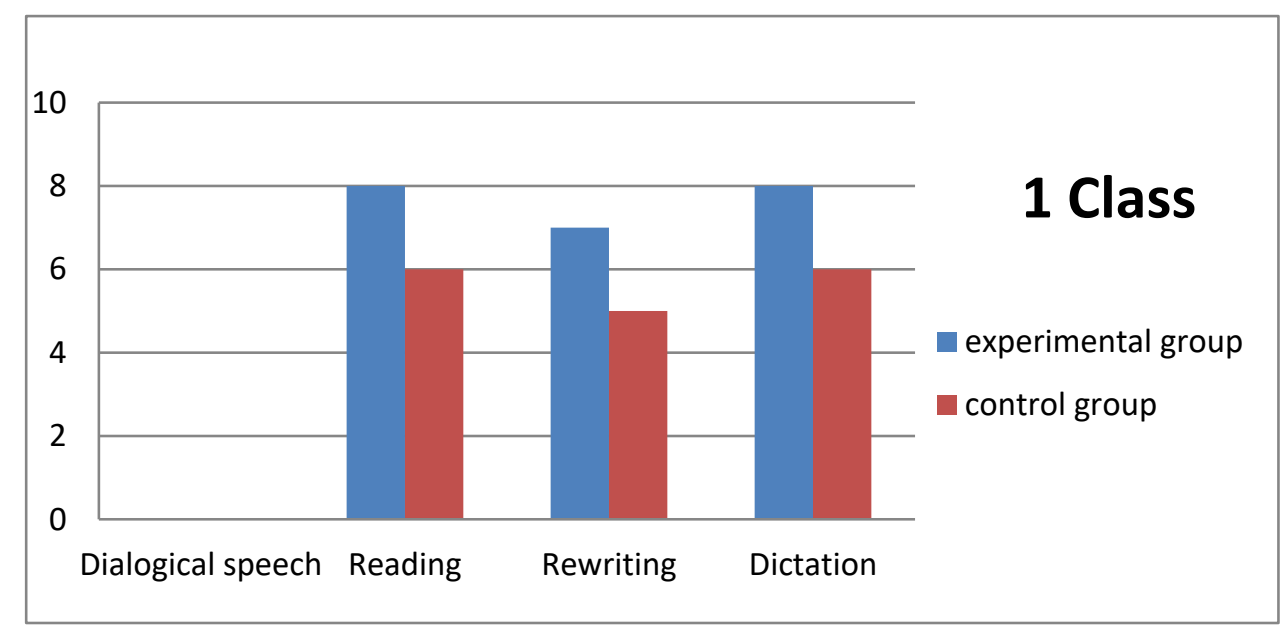

Figure 2. Assessment of the Level of Educational Achievements of First Grade Students in the Ukrainian Language 


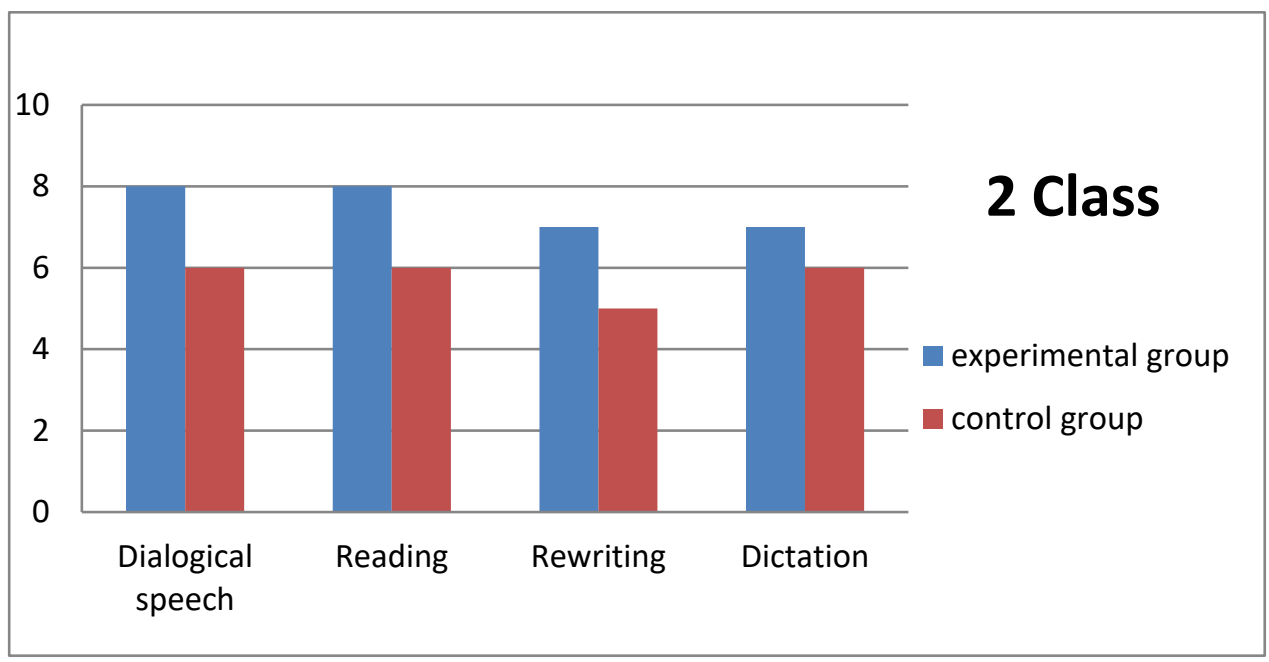

Figure 3. Assessment of the Level of Educational Achievements of Students of Other Grades in the Ukrainian Language

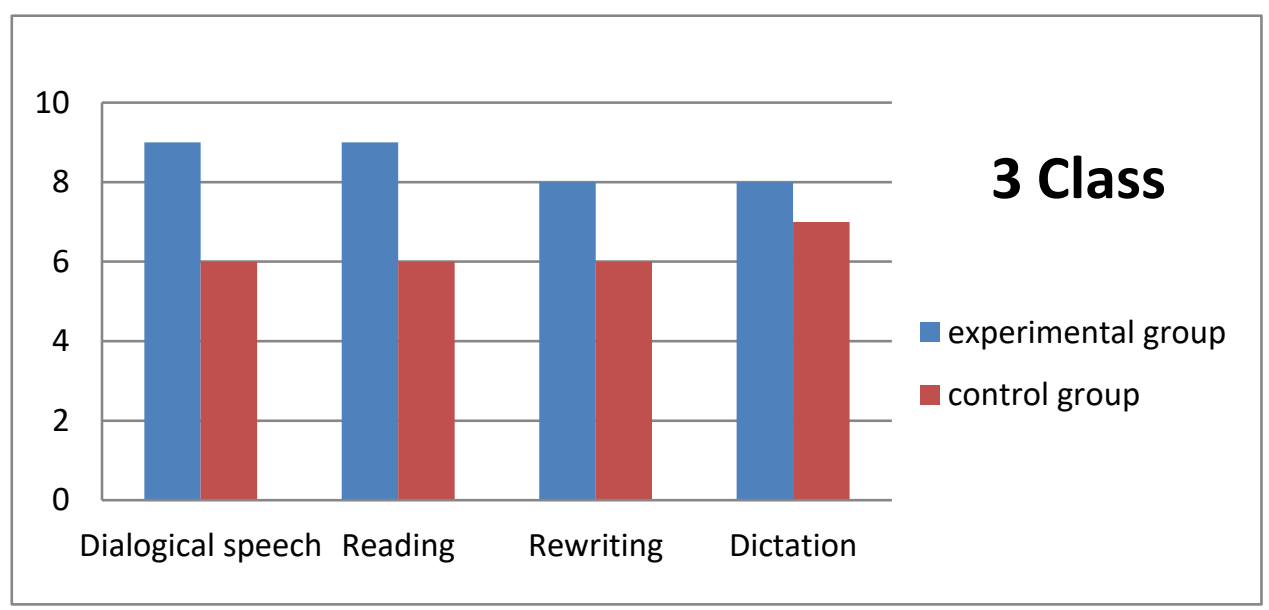

Figure 4. Assessment of the Level of Academic Achievement of Third Grade Students in the Ukrainian Language

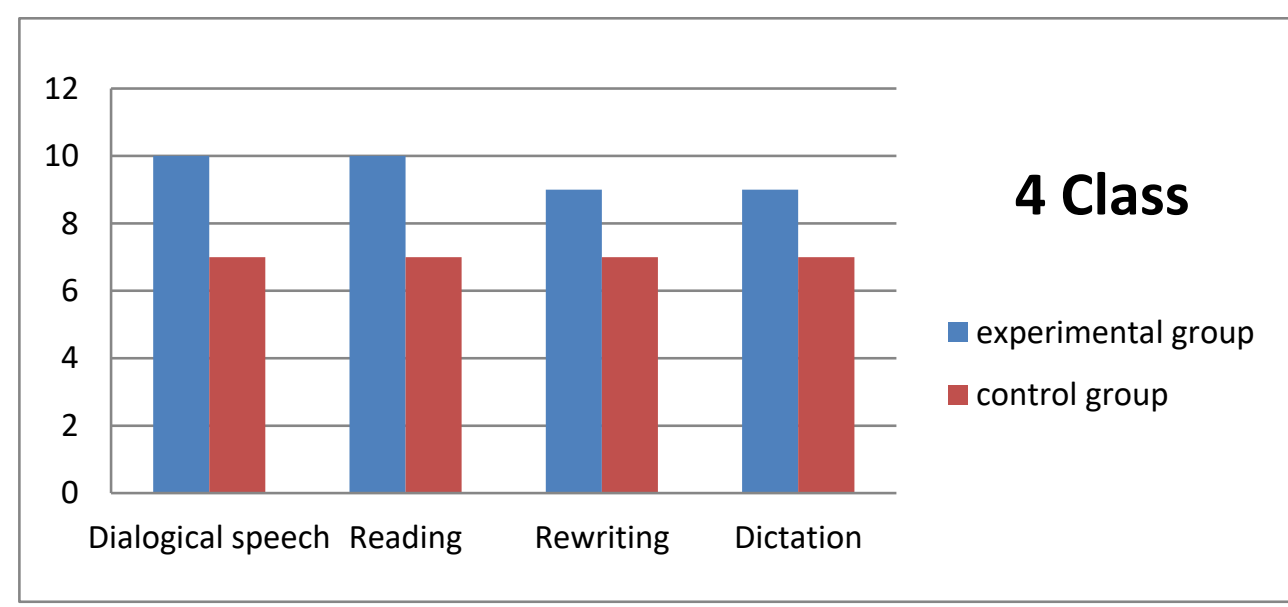

Figure 5. Assessment of the Level of Academic Achievement of Fourth Grade Students in the Ukrainian Language 
Table 5. Results of Assessing the Level of Educational Achievements of Students in the Ukrainian Language and Mathematics

\begin{tabular}{|c|c|c|c|}
\hline Assessment object & Class & Experimental group, points & Control group, points \\
\hline \multicolumn{4}{|l|}{ Ukrainian language } \\
\hline Listening & 1 & 10 & 7 \\
\hline \multirow[t]{3}{*}{ dialogical speech } & 2 & 8 & 6 \\
\hline & 3 & 9 & 6 \\
\hline & 4 & 10 & 7 \\
\hline \multirow[t]{4}{*}{ Reading } & 1 & 8 & 6 \\
\hline & 2 & 8 & 6 \\
\hline & 3 & 9 & 6 \\
\hline & 4 & 10 & 7 \\
\hline \multirow[t]{4}{*}{ write-off } & 1 & 7 & 5 \\
\hline & 2 & 7 & 5 \\
\hline & 3 & 8 & 6 \\
\hline & 4 & 9 & 7 \\
\hline \multirow[t]{4}{*}{ Dictation } & 1 & 8 & 6 \\
\hline & 2 & 7 & 6 \\
\hline & 3 & 8 & 7 \\
\hline & 4 & 9 & 7 \\
\hline \multirow[t]{4}{*}{ Points total } & 1 & 33 & 24 \\
\hline & 2 & 30 & 23 \\
\hline & 3 & 34 & 25 \\
\hline & 4 & 38 & 28 \\
\hline \multirow{4}{*}{$\begin{array}{l}\text { The level of educational achievement of students in } \\
\text { Ukrainian }\end{array}$} & 1 & sufficient & average \\
\hline & 2 & sufficient & average \\
\hline & 3 & sufficient & sufficient \\
\hline & 4 & high & sufficient \\
\hline \multicolumn{4}{|l|}{ Mathematics } \\
\hline \multirow[t]{4}{*}{ computing skills } & 1 & 7 & 5 \\
\hline & 2 & 8 & 5 \\
\hline & 3 & 9 & 6 \\
\hline & 4 & 9 & 6 \\
\hline \multirow[t]{4}{*}{ problem-solving skills } & 1 & 7 & 5 \\
\hline & 2 & 7 & 5 \\
\hline & 3 & 8 & 6 \\
\hline & 4 & 9 & 6 \\
\hline \multirow{4}{*}{$\begin{array}{l}\text { application of properties, rules, algorithms, } \\
\text { dependencies }\end{array}$} & 1 & 7 & 5 \\
\hline & 2 & 8 & 6 \\
\hline & 3 & 9 & 7 \\
\hline & 4 & 10 & 7 \\
\hline \multirow{4}{*}{$\begin{array}{l}\text { execution } \\
\text { measurements and geometric constructions }\end{array}$} & 1 & 6 & 5 \\
\hline & 2 & 7 & 5 \\
\hline & 3 & 8 & 6 \\
\hline & 4 & 8 & 7 \\
\hline \multirow[t]{4}{*}{ Mathematics score } & 1 & 27 & 20 \\
\hline & 2 & 31 & 21 \\
\hline & 3 & 34 & 25 \\
\hline & 4 & 36 & 26 \\
\hline \multirow{4}{*}{$\begin{array}{l}\text { The level of educational achievement of students } \\
\text { mathematics }\end{array}$} & 1 & sufficient & average \\
\hline & 2 & sufficient & average \\
\hline & 3 & sufficient & average \\
\hline & 4 & sufficient & sufficient \\
\hline
\end{tabular}


As this study has shown, the use of such interactive methods as "Microphone", "Brainstorming", "Take a position", "Studying-learning", "Working in pairs", "Talk-show", " Jigsaw ", "Circle of ideas", "Aquarium" and "Role-playing games" already for 1 academic year can help to increase the level of educational achievements of students in grades 1 , 2 from average (control group) to sufficient (experimental group). In the fourth grade - from sufficient (control group) to high (experimental group). The use of the same methods in mathematics lessons changed the level of achievement of students in grades 1-3 from average (control group) to sufficient (experimental group) (Table 5).

The results of the survey of students in grades 1-4 regarding their attitude to learning and the amount of time spent on doing homework, which was carried out both in the experimental and control groups, are presented in Table 6. In addition, the students of the experimental group determined their attitude to interactive teaching methods.

Table 6. Results of the Survey of Students in Grades 1-4

\begin{tabular}{|c|c|c|c|c|c|}
\hline & Class & 1 & 2 & 3 & 4 \\
\hline № & Questionnaire questions & \multicolumn{4}{|c|}{$\begin{array}{l}\text { The number of students in the experimental (control) group who } \\
\text { answered "Yes" to the questions of the questionnaire }\end{array}$} \\
\hline 1 & Are you interested in Russian lessons? & $\begin{array}{l}19 / 92 \% \\
(15 / 71 \%)\end{array}$ & $\begin{array}{l}45 / 94 \% \\
(33 / 67 \%)\end{array}$ & $\begin{array}{l}52 / 91 \% \\
(41 / 71 \%)\end{array}$ & $\begin{array}{l}47 / 90 \% \\
(35 / 67 \%)\end{array}$ \\
\hline 2 & Are you interested in math lessons? & $\begin{array}{l}18 / 86 \% \\
(14 / 67 \%)\end{array}$ & $\begin{array}{l}44 / 92 \% \\
(31 / 63 \%)\end{array}$ & $\begin{array}{l}50 / 88 \% \\
(39 / 67 \%)\end{array}$ & $\begin{array}{l}44 / 84 \% \\
(32 / 62 \%)\end{array}$ \\
\hline 3 & Do you spend a lot of time preparing homework? & $\begin{array}{l}6 / 29 \% \\
(12 / 57 \%)\end{array}$ & $\begin{array}{l}13 / 27 \% \\
(35 / 73 \%)\end{array}$ & $\begin{array}{l}24 / 42 \% \\
(48 / 83 \%)\end{array}$ & $\begin{array}{l}28 / 27 \% \\
(46 / 88 \%)\end{array}$ \\
\hline \multirow[t]{12}{*}{4} & $\begin{array}{l}\text { On Ukrainian language and mathematics lessons } \\
\text { you like most: } \\
\text { work on a task with a neighbor at the desk }\end{array}$ & $16 / 76 \%$ & $42 / 88 \%$ & $46 / 80 \%$ & $43 / 83 \%$ \\
\hline & work on the task together with classmates & $13 / 62 \%$ & $31 / 65 \%$ & $35 / 61 \%$ & $30 / 58 \%$ \\
\hline & watch the teacher work on the assignment & $9 / 43 \%$ & $23 / 47 \%$ & $25 / 44 \%$ & $24 / 46 \%$ \\
\hline & play games under the guidance of a teacher & $17 / 81 \%$ & $38 / 78 \%$ & $27 / 47 \%$ & $20 / 39 \%$ \\
\hline & $\begin{array}{l}\text { answer the question when you have a microphone } \\
\text { in your hands }\end{array}$ & $16 / 76 \%$ & $42 / 88 \%$ & $34 / 60 \%$ & $26 / 50 \%$ \\
\hline & get to the poster that shows the answer to the task & $17 / 81 \%$ & $37 / 76 \%$ & $35 / 61 \%$ & $33 / 63 \%$ \\
\hline & to be a teacher and teach classmates & $15 / 71 \%$ & $41 / 85 \%$ & $47 / 82 \%$ & $43 / 83 \%$ \\
\hline & read in cast text or translate it in cast & $12 / 57 \%$ & $40 / 83$ & $49 / 86 \%$ & $38 / 73 \%$ \\
\hline & play «Talk show» & $11 / 52 \%$ & $37 / 76 \%$ & $48 / 84 \%$ & $44 / 85 \%$ \\
\hline & observe how classmates solve a problem & $8 / 38 \%$ & $27 / 56 \%$ & $35 / 61 \%$ & $43 / 83 \%$ \\
\hline & $\begin{array}{l}\text { work in different groups while solving the same } \\
\text { problem }\end{array}$ & $15 / 71 \%$ & $32 / 67 \%$ & $37 / 64 \%$ & $25 / 48 \%$ \\
\hline & formulate different ideas for solving a problem & $16 / 76 \%$ & $36 / 74 \%$ & $42 / 73 \%$ & $33 / 63 \%$ \\
\hline
\end{tabular}

A survey of students in grades 1-4 showed that interactive teaching methods contribute to the growth of students interest in learning the Ukrainian language and mathematics by more than $20 \%$ (Table 6). At the same time, the use of these methods allows you to reduce the time for preparing home tasks, while not reducing the level of educational achievements of students (Tables 5, 6).

The questionnaire also made it possible to determine which teaching methods are preferred by the students. It was revealed that priorities change with age. For example, the «Jigsaw» method is preferred by $71 \%$ of students in the first grade, $67 \%$ in the second, $64 \%$ in the third and $48 \%$ in the fourth. The «Aquarium» method, on the contrary: $38 \%$ - first graders, $56 \%$ - second grade students, $61 \%$ - third grade and $83 \%$ - fourth grade. The desire to imitate the teacher, as well as to work on an assignment in a pair or a group (Table 6), does not depend on the age of the students, which partially coincides with the frequent choice of the methods «Studying-learning», «Work in pairs», «Brainstorming» for work with students in the classroom.

A certain intergroup variance, which is a characteristic of the heterogeneity of the sample caused by the experiment in various institutions of general secondary education, ranged from 316 to 1267. At the same time, it differed from 
the intragroup variance, which is evidence of the inequality of the null hypothesis.

Applying the Pearson criterion and comparing $\chi\left\llcorner^{\wedge} 2\right.$ for the experimental and control groups, we found that $\chi 1^{\wedge} 2>$ $\chi 2^{\wedge} 2$, where $\chi 1^{\wedge} 2$ was obtained for the experimental group, and $\chi 2^{\wedge} 2$ - for the control group. This is proof of the relationship between the use of interactive teaching methods and the level of educational achievement of students. At the same time, Cohen's coefficient in the experimental group reached 1.0, and in the control group, 0.5. This testifies to the high efficiency of using interactive teaching methods in primary grades.

\section{Discussion}

The aim of this study was to test the effectiveness of the use of interactive teaching methods in primary grades. As it turned out, such teaching methods as "Microphone", "Brainstorming", "Take a position", "Studying-learning", "Working in pairs", "Talk-show", " Jigsaw", "Circle of ideas", "Aquarium", "Role-playing games" contribute to the growth of students' interest in learning the Ukrainian language and mathematics. Also, their skillful, timely use, in accordance with the age and individual characteristics of students, determines an increase in the level of educational achievements.

A study of 52 grade students from Southern Africa found that interactive radio learning improved student performance in English as a foreign language by $6.7 \%$ in just 33 lessons; $13 \%$ increase in 66 lessons (Elliot \& Lashley, 2017). In Bolivia, second grade math learning outcomes improved from $47 \%$ to $66 \%$; in the fourth grades from $47 \%$ to $57 \%$. At the same time, the experiment took place in schools that have problems with professional staffing, as well as a shortage of textbooks and other materials necessary for teaching. The use of radio teaching in such schools already in the first grade improves the results of educational tests in reading, writing and knowledge of language and mathematics by $27 \%$ compared to regular schools (Elliot \& Lashley, 2017).

A study in Malaysia of 29 first grade students and 27 grade 3 students found that using playful learning platforms increases motivation to learn and build and improve writing skills (Azam et al., 2019). Test results (Samat, 2020) confirm the positive effect of using the interactive model in teaching primary school students on reading comprehension, as measured by a 4.75 increase in the average test score.

There were 129 schools that had little effect on math coaching among peers (Thurston et al., 2020). It has also been proven that such training depends on many factors, for example, on the popularity of the student in the student community. This trend is not constant. Scientists have shown that training students with students of all ages does not have a beneficial effect.

The study was conducted among 200 students, 30 teachers and 30 parents from state and non-state schools in Kosovo. The expediency of using interactive teaching methods to implement a differentiated approach to students has been demonstrated (Ismajli \& Imami-Morina, 2018). It was revealed that about half of the students prefer to work in pairs.

In the United States, a study in 389 children confirmed a positive effect on the development of children's math skills in special math programs after just 12 weeks of use (Outhwaite et al., 2019). Therefore, scientists recommend a balanced use of mathematical programs in the educational process. A study (Saputri et al., 2018) of 147 students and 5 primary school teachers identified the need for game-based interactive multimedia. Students enjoy games, adventure, active interaction, problem solving and challenge.

\section{Conclusions}

The search and use of productive teaching methods in the educational process today is one of the priority tasks of modern educational institutions. To solve it, in this work, a model has been developed and conducted, involving the use of interactive teaching methods in primary school. It has been established that today not all teachers use interactive teaching methods. In the course of the work, the high efficiency of using such interactive teaching methods as "Microphone", "Brainstorming", "Take a position", "Studying-learning", "Working in pairs", "Talk-show", «Jigsaw», «Circle of ideas», «Aquarium» and «Role-playing games». With the help of a questionnaire, it was proved that the methods selected in accordance with the age and educational needs of students contribute to an increase in students' interest in the disciplines studied. In addition, they have a positive effect on the growth of the level of educational achievement of students. The results of this study can be useful for teachers working in grades $1-4$, as well as researchers who are looking for new and researching already known teaching methods that can be used in primary school. Further research should be carried out to monitor the compliance of existing teaching methods in pedagogy with the educational needs of students. It is also necessary to develop and introduce new interactive methods and investigate their impact on student achievement. 


\section{References}

Alsawalha, M. (2018). Interactive educational activities and their impacts on student's innovation, teaching and learning at jubail industrial college (KSA). American Journal of Educational Research, 6(2), 117-122. http://doi.org/10.12691/education-6-2-4

Anastasiadis, T., Lampropoulos, G., \& Siakas, K. (2018). Digital game-based learning and serious games in education. International Journal of Advances in Scientific Research and Engineering (IJASRE), 4(12), 139-144. http://doi.org/10.31695/IJASRE.2018.33016

Azam, F. K. K., Fadhil, F., \& Yunus, M. M. (2019). Enhancing ESL learners' Writing Skills via ProvWrit. International Journal of Academic Research in Business and Social Sciences, 9(1), 660-669. http://doi.org/10.6007/IJARBSS/v9-i1/5467

Bagila, S., Kok, A., Zhumabaeva, A., Suleimenova, Z., Riskulbekova, A., \&Uaidullakyzy, E. (2019). Teaching primary school pupils through audio-visual means. International Journal of Emerging Technologies in Learning (iJET), 14(22), 122-140. https://doi.org/10.3991/ijet.v14i22.11760

Dita, P. P. S., Utomo, S., \& Sekar, D. A. (2021). Implementation of Problem Based Learning (PBL) on interactive learning media. Journal of Technology and Humanities, 2(2), 24-30. https://doi.org/10.53797/jthkkss.v2i2.4.2021

Tomuletiu, E.-A., Filpisan, M., Stoica, M., Gorea, B., Slev, A. M., \& Moraru, A. (2011). The relation between pupils' learning style and educational performance. Procedia-Social and Behavioral Sciences, 15, 1502-1506. http://doi.org/10.1016/j.sbspro.2011.03.319

Elliot, V., \& Lashley, L. (2017). The effectiveness of Interactive Radio Instruction (IRI) within selected Primary Schools in Region Number Four (4). Social Science Learning Education Journal, 2(9), 22-37. https://www.researchgate.net/publication/319854646

Emeljanovas, A., Miežienė, B., Mok, M. M. C., Chin, M. K., Česnaitienė, V., Fatkulina, N. ... Suárez, A. D. (2018). Efecto de un programa interactivo durante los descansos escolares en las actitudes hacia la actividad física de escolares de primaria. Anales de Psicología, 34(3), 580-586. http://dx.doi.org/10.6018/analesps.34.3.326801

Fauzi, I., \& Khusuma, I. H. S. (2020). Teachers' elementary school in online learning of COVID-19 pandemic conditions. Jurnal Iqra': Kajian Ilmu Pendidikan, 5(1), 58-70. https://doi.org/10.25217/ji.v5i1.914

Guran, A. M., Cojocar, G. S., \& Dioşan, L. (2020). A step towards preschoolers' satisfaction assessment support by facial expression emotions identification. Procedia Computer Science, 176, 632-641. https://doi.org/10.1016/j.procs.2020.08.065

Iasha, V., Sumantri, M. S., Sarkadi, S., \& Rachmadtullah, R. (2018). Development media interactive learning in education pancasila and citizenship education to improve tolerance of students in elementary school. Advances in Social Science, Education and Humanities Research, 251, 311-314. https://doi.org/10.2991/acec-18.2018.71

Ien, L. K., Yunus, M. M., \& Embi, M. A. (2017). Build me up: Overcoming writing problems among pupils in a rural primary school in Belaga, Sarawak, Malaysia. Jurnal Pendidikan Humaniora, 5(1), 1-7. http://dx.doi.org/10.17977/um030v5i12017p001

Indicative requirements for monitoring and evaluating the academic achievements of primary school students. № 1009. (2016).

Ismajli, H., \& Imami-Morina, I. (2018). Differentiated instruction: Understanding and applying interactive strategies to meet the needs of all the students. International Journal of Instruction, 11(3), 207-218. https://doi.org/10.12973/iji.2018.11315a

Kacetl, J., \& Semradova, I. (2020). Reflection on blended learning and e-learning - case study. Procedia Computer Science, 176, 1322-1327. https://doi.org/10.1016/j.procs.2020.09.141

Kocman, D., Števanec, T., Novak, R., \& Kranjec, N. (2020). Citizen science as part of the primary school curriculum: A case study of a technical day on the topic of noise and health. Sustainability, 12(23), 10213. http://doi.org/10.3390/su122310213

Lebedev, G., Zhovnerchuk, E., Zhovnerchuk, I., \& Moskovenko, A. (2020). Remote recognition of human emotions using deep machine learning of artificial neural networks. Procedia Computer Science, 176, 1517-1522. https://doi.org/10.1016/j.procs.2020.09.162 
Luyten, H., Merrell, C., \& Tymms, P. (2020). Absolute effects of schooling as a reference for the interpretation of educational intervention effects. Studies in Educational Evaluation, 67, 100939. https://doi.org/10.1016/j.stueduc.2020.100939

Mekacher, L. (2019). Augmented Reality (AR) and Virtual Reality (VR): The future of interactive vocational education and training for people with handicap. International Journal of Teaching, Education and Learning, 3(1). https://dx.doi.org/10.20319/pijtel.2019.31

Oltievna, K. F., \& Aktamovna, A. D. (2020). The actuality and the content of forming critical thinking skills of primary school pupils. Psychology and Education Journal, 57(8), 555-563. https://doi.org/10.17762/pae.v57i8.986

Outhwaite, L. A., Faulder, M., Gulliford, A., \& Pitchford, N. J. (2019). Raising early achievement in math with interactive apps: A randomized control trial. Journal of Educational Psychology, 111(2), 284. https://doi.org/10.1037/edu0000286

Parmigiani, D., Benigno, V., Giusto, M., Silvaggio, C., \& Sperandio, S. (2020). E-inclusion: online special education in Italy during the Covid-19 pandemic. Technology, Pedagogy and Education, 30(1), 1-14. http://doi.org/10.1080/1475939X.2020.1856714

Pitchford, N. J., Kamchedzera, E., Hubber, P. J., \& Chigeda, A. L. (2018). Interactive apps promote learning of basic mathematics in children with special educational needs and disabilities. Frontiers in Psychology, 9, 262. http://doi.org/10.3389/fpsyg.2018.00262

Ponomarova, V., \& Lebedenko, K. (2021). Interactive tools of increasing primary school pupils'motivation in the native language learning. Collection of scientific papers http://doi.org/10.36074/logos-05.02.2021.v4.35

Puspitarini, Y. D., \& Hanif, M. (2019). Using learning media to increase learning motivation in elementary school. Anatolian Journal of Education, 4(2), 53-60. https://doi.org/10.29333/aje.2019.426a

Putri, R. S., Purwanto, A., Pramono, R., Asbari, M., Wijayanti, L. M., \& Hyun, C. C. (2020). Impact of the COVID-19 pandemic on online home learning: an explorative study of primary schools in Indonesia. International Journal of Advanced Science and Technology, 29(5), 4809-4818. Retrieved from https://www.researchgate.net/publication/341194197

Rachmadtullah, R. M. S. Z., Ms, Z., \& Sumantri, M. S. (2018). Development of computer-based interactive multimedia: study on learning in elementary education. International Journal of Engineering \& Technology, 7(4), 2035-2038. http://doi.org/10.14419/ijet.v7i4.16384

Rotova, N. A. (2018). Development of independence among future primary school teachers by applying interactive learning methods. Journal of Education and e-Learning Research, 5(2), 118-121. http://doi.org/10.20448/journal.509.2018.52.118.121

Samat, A. (2020). The effectiveness of multimedia learning in enhancing reading comprehension among indigenous pupils. Arab World English Journal, 11(2), 290-302. https://dx.doi.org/10.24093/awej/voll1 no2.20

Saputri, D. Y., Rukayah, R., \& Indriayu, M. (2018). Need assessment of interactive multimedia based on game in elementary school: A challenge into learning in 21st century. International Journal of Educational Research Review, 3(3), 1-8. http://doi.org/10.24331/ijere.411329

Shkvyr, O., Haidamashko, I., \& Tafintseva, S. (2020). Developing critical thinking in younger pupils using ICT. BRAIN. Broad Research in Artificial Intelligence and Neuroscience, 11(2), 230-242. https://doi.org/10.18662/brain/11.2/85

Shraddha, B. H., Iyer, N. C., Kotabagi, S., Mohanachandran, P., Hangal, R. V., Patil, N. ... Patil, J. (2020). Enhanced learning experience by comparative investigation of pedagogical approach: Flipped classroom. Procedia Computer Science, 172, 22-27. https://doi.org/10.1016/j.procs.2020.05.003

Thurston, A., Roseth, C., Chiang, T. H., Burns, V., \& Topping, K. J. (2020). The influence of social relationships on outcomes in mathematics when using peer tutoring in elementary school. International Journal of Educational Research Open, 1, 100004. https://doi.org/10.1016/j.ijedro.2020.100004

Veldman, M. A., Doolaard, S., Bosker, R. J., \& Snijders, T. A. B. (2020). Young children working together. Cooperative learning effects on group work of children in Grade 1 of primary education. Learning and Instruction, 67, 101308. https://doi.org/10.1016/j.learninstruc.2020.101308 


\section{Copyrights}

Copyright for this article is retained by the author(s), with first publication rights granted to the journal.

This is an open-access article distributed under the terms and conditions of the Creative Commons Attribution license (http://creativecommons.org/licenses/by/4.0/). 